\section{Molecular genetics of microvascular disease in diabetic retinopathy}

KM Warpeha and U Chakravarthy

\begin{abstract}
Diabetic retinopathy is a sight-threatening complication of the retinal microvasculature. While important environmental factors have been clearly identified as influencing its development, increasing evidence suggests that diabetic retinopathy has a genetic component. A variety of studies have explored associations between candidate genes and frequency and severity of retinopathy. Overall, this review has found that the majority of candidate genes studied exhibit weak or no association with retinopathy status, and where associations have been detected these results have not been replicated in multiple populations. This may reflect inaccurate case definition, small subject numbers and possibly inadequate markers for genetic studies

Eye (2003) 17, 305-311. doi:10.1038/

sj.eye. 6700348
\end{abstract}

Keywords: diabetic retinopathy; genetic susceptibility; polymorphisms

\section{Genetic susceptibility to diabetic retinopathy}

It is recognised that polymorphic variability in the genetic make-up of an individual can profoundly influence the expression of a gene and its response to environmental factors. ${ }^{1,2}$ Useful clinical markers for genetic susceptibility to a disease are either familial aggregation or a variation in disease frequency, which are not explained by environmental, biochemical, or biological risk factors. Diabetic retinopathy (DR) displays these characteristics as clinical studies on human subjects with diabetes reveal substantial variation in the onset and severity of retinopathy that are not fully explained by the known risk factors such as duration of diabetes, level of glycaemic control, or concomitant vascular disease. ${ }^{3,4}$ The risk of severe DR in the siblings of affected individuals is substantially increased, ${ }^{5}$ and the Diabetes Control \& Complications Trial has shown that retinopathy tends to cluster in families. ${ }^{4}$ Furthermore, differences in the frequency of disease in ethnic populations ${ }^{6}$ also suggest that genetic influences are operating in DR. With the complex metabolic environment of the retina, many risk factors have been proposed in the past. $^{7,8}$

The search for genetic factors in multifactorial, complex late-onset human diseases is characterised by two approaches: genome-wide scans for markers linked to disease and candidate genes studied individually based on the putative function of the gene product. In terms of DR, few studies have employed the former method. Recently, Imperatore $e t a l^{9}$ undertook a genome-wide scan for susceptibility genes to diabetic retinopathy (and nephropathy) in families using affected sib-pair linkage analysis. There were indications that elements on chromosomes 3 and 9 influenced both nephropathy and retinopathy, but no clear genomic region was designated for retinopathy alone. ${ }^{9}$

\section{Candidate genes for retinopathy}

Association between genetic variability and retinopathy may be because of increased frequency or increased severity of retinopathy within the population of interest. A large number of candidate genes have been examined in subjects with diabetes, but few groups have identified a strong association between a gene and the frequency or severity of retinopathy. Most published studies have been based on small patient samples, and case definitions were not based on prospectively agreed and standardised criteria. Moreover, selection of genes for association studies in DR poses particular difficulties, as many of the obvious candidate genes are involved with the normal function and regulation of the microvasculature in the retina. In this review, we focus on groups
Ophthalmology and Vision Science

Queen's University and Royal Hospitals Institute of Clinical Science Belfast, UK

\section{Correspondence:}

U Chakravarthy

Ophthalmology and Vision

Science

Queen's University and

Royal Hospitals

Institute of Clinical Science

Grosvenor Road

Belfast BT12 6BA, UK

Tel: +44 2890330744

Fax: +44 2890240503

E-mail: u.Chakravarthy@ qub.ac.uk

Received: 7 November 2001 Accepted in revised form: 18 January 2002 
Table 1 Summary of studies on associations between genetic markers and diabetic retinopathy

\begin{tabular}{|c|c|c|c|c|c|c|c|}
\hline Gene & Product & Marker & $\begin{array}{l}\text { Association } \\
\text { with }\end{array}$ & Ethnicity & $\begin{array}{l}\text { Type of } \\
\text { Diabetes }\end{array}$ & Reference & Sample size \\
\hline \multirow[t]{9}{*}{ AR2 } & \multirow[t]{9}{*}{ Aldose reductase } & Substitution $^{\mathrm{a}}$ & Retinopathy & Asian & 2 & Kao et $a l^{15}$ & NR=97; AR=67 (adolescents) \\
\hline & & \multirow{8}{*}{ Microsatellite } & No retinopathy & Multiethnic & 2 & Olmos et al ${ }^{16}$ & $\mathrm{AR}=27$ \\
\hline & & & No retinopathy & Asian & 2 & Ko et $a l^{17}$ & $\mathrm{NR}=22 ; \mathrm{AR}=22$ \\
\hline & & & Retinopathy & Asian & 2 & Fujisawa $e t$ al ${ }^{18}$ & $\mathrm{NR}=83 ; \mathrm{PPR}=87$ \\
\hline & & & Retinopathy & Asian & 2 & Ichikawa et al $1^{19}$ & $\mathrm{NR}=30 ; \mathrm{SR}=30 ; \mathrm{PPR}=27$ \\
\hline & & & Retinopathy & Asian & 2 & Ikegishi et $a l^{20}$ & $\mathrm{NR}=34 ; \mathrm{PPR}=27$ \\
\hline & & & Retinopathy & Caucasian & 1 & Demaine $e t a l^{22}$ & $\mathrm{NR}=70 ; \mathrm{PPR}=159$ \\
\hline & & & None & Multiethnic & 1 & Chistyakov et al $l^{21}$ & $\mathrm{NR}=31 ; \mathrm{PPR}=19$ \\
\hline & & & None & Caucasian & 1 & Heesom et $a l^{13}$ & (Neph study) stratified for DR \\
\hline \multirow{7}{*}{$\begin{array}{l}\text { HLA } \\
\text { region } \\
\text { genes }\end{array}$} & \multirow[t]{7}{*}{ Region of chromosome $6 \mathrm{p}$} & \multirow[t]{7}{*}{ Various } & Retinopathy & African & 1 & Cisse $e t a l^{23}$ & Not known \\
\hline & & & Retinopathy & Caucasian & 1 & Falck et $a l^{24}$ & $\mathrm{NR}=52 ; \mathrm{AR}=51$ (adolescents) \\
\hline & & & Retinopathy & Caucasian & 1 & Agardh et $a l^{25}$ & $\mathrm{NR}$ or $\mathrm{SR}=28 ; \mathrm{PPR}=28$ \\
\hline & & & None & Caucasian & 1 & Stewart et $a l^{26}$ & $\mathrm{NR}=39 ; \mathrm{AR}=20$ (adolescents) \\
\hline & & & None & Asian & 2 & Hawrami et al $2^{28}$ & $\mathrm{NR}=45 ; \mathrm{PPR}=40$ \\
\hline & & & None & Caucasian & 1 & Serrano-Rios $e t a l^{27}$ & $\mathrm{AR}=32$ \\
\hline & & & & & 2 & Serrano-Rios et $_{a l^{27}}$ & $\mathrm{AR}=35$ \\
\hline IgG & Immunoglobulin subclass heavy chains & Allotypes & Retinopathy & Caucasian & 1 & Stewart et $a l^{26}$ & $\mathrm{NR}=58 ; \mathrm{AR}=44$ (adolescents) \\
\hline $\operatorname{IgM} S \mu$ & $\begin{array}{l}\text { Immunoglobulin } M \text { heavy chain switch } \\
\text { region }\end{array}$ & Substitution & Retinopathy & Asian & 2 & Hawrami et $a l^{28}$ & $\mathrm{NR}=45 ; \mathrm{PPR}=40$ \\
\hline \multirow[t]{3}{*}{ GLUT1 } & \multirow[t]{3}{*}{ Glucose transporter 1} & \multirow{3}{*}{$\begin{array}{l}\text { Nucleotide } \\
\text { substitution }\end{array}$} & None & Caucasian & 2 & Guitterez et $a l^{29}$ & $\mathrm{NR}=92 ; \mathrm{AR}=68$ \\
\hline & & & None & Caucasian & 1 & Hodgkinson $e t a l^{30}$ & $\mathrm{NR}=44 ; \mathrm{AR}=30$ (neph study) \\
\hline & & & None & Asian & 2 & Liu $e t a l^{31}$ & $\mathrm{AR}=45$ (neph study) \\
\hline \multirow[t]{2}{*}{ PAI } & \multirow[t]{2}{*}{ Plasminogen activator inhibitor } & \multirow[t]{2}{*}{$\begin{array}{l}\text { Insertion/deletion and } \\
\text { nucleotide substitution }\end{array}$} & None & Indian & 2 & Nagi et $a l^{32}$ & $\mathrm{NR}=101 ; \mathrm{AR}=70$ \\
\hline & & & None & Caucasian & 1 & Tarnow et al $l^{33}$ & (Neph study) stratified for DR \\
\hline APOE & Apolipoprotein E & Allelic variation & None & Caucasian & 1 & Tarnow et $a l^{33}$ & (Neph study) stratified for DR \\
\hline TNF & Tumour necrosis factor in $\mathrm{MHC}$ & Microsatellite & Retinopathy & Asian & 2 & Hawrami et $a l^{34}$ & $\mathrm{NR}=46 ; \mathrm{PPR}=53$ \\
\hline \multirow[t]{2}{*}{$\beta 3-\mathrm{AR}$} & \multirow[t]{2}{*}{$\beta-3$ Adrenoreceptor } & \multirow[t]{2}{*}{ Substitution } & Retinopathy & Asian & 2 & Sakane et al ${ }^{35}$ & $\mathrm{NR}=121 ; \mathrm{NP}=48 ; \mathrm{PR}=46$ \\
\hline & & & None & Caucasian & 1 & Vendrell et $a l^{36}$ & $\mathrm{NP}=56 ; \mathrm{PR}=12$ \\
\hline \multirow[t]{2}{*}{ PON1 } & \multirow[t]{2}{*}{ Paraoxonase 1} & \multirow[t]{2}{*}{ Substitution } & Retinopathy & Multiethnic & 2 & Kao et $a l^{37}$ & $\mathrm{NR}=119 ; \mathrm{AR}=80$ \\
\hline & & & None & Multiethnic & 2 & Mackness et al ${ }^{39}$ & $\mathrm{NR}=93 ; \mathrm{AR}=101$ \\
\hline$\alpha 2 \beta 1 \mathrm{I}$ & $\alpha 2 \beta 1$ Integrin (platelet collagen receptor) & $\begin{array}{l}\text { Various (silent base) } \\
\text { changes and } \\
\text { nucleotide transition }\end{array}$ & Retinopathy & Asian & 2 & Matsubara et $a l^{39}$ & $\mathrm{NR}=108 ; \mathrm{AR}=119$ \\
\hline \multirow{2}{*}{$\begin{array}{l}\text { Collagen } \\
\text { IV } \alpha 1\end{array}$} & \multirow[t]{2}{*}{ Basement membrane protein } & \multirow[t]{2}{*}{ Substitution } & None & Caucasian & 2 & Alcolado et $a l^{40}$ & $\mathrm{PR}=43$ \\
\hline & & & None & Caucasian & 1 & Chen $e t a l^{41}$ & (Neph study) stratified for DR \\
\hline $\mathrm{G} \beta 3$ & $\beta$-Subunit of heterotrimeric G-protein & Substitution & None & Caucasian & 1 & Shcherbak and Schwartz ${ }^{42}$ & $\mathrm{NR}=96 ; \mathrm{AR}=76$ \\
\hline NPY & Neuropeptide Y & Substitution & Retinopathy & Caucasian & 2 & Niskanen $e t a l^{43}$ & $\mathrm{NR}=46 ; \mathrm{AR}=40$ \\
\hline \multirow[t]{4}{*}{ ACE } & \multirow[t]{4}{*}{ Angiotensin-converting enzyme } & \multirow[t]{4}{*}{ Insertion/deletion } & None & Caucasian & 2 & Guitterez et al $l^{48}$ & $\mathrm{NR}=92 ; \mathrm{AR}=68$ \\
\hline & & & None & Asian & 2 & Fujisawa et al ${ }^{49}$ & Meta-analysis (18 studies) \\
\hline & & & None & Caucasian & 1 & Nagi et $a l^{50}$ & $\mathrm{NP}=92 ; \mathrm{PR}=94$ \\
\hline & & & Retinopathy & Asian & 2 & Nagi et $a l^{50}$ & $\mathrm{NP}=186 ; \mathrm{PR}=177$ \\
\hline
\end{tabular}




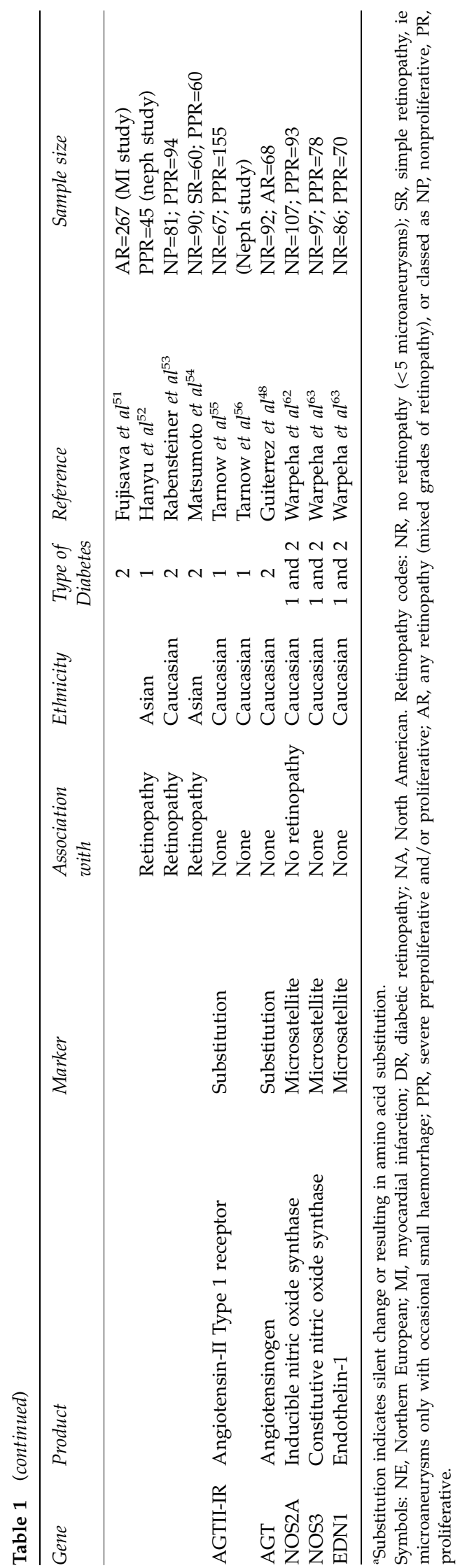

of genes involved in distinct metabolic and functional pathways known to be affected in diabetes. In Table 1, we provide a summary of the studies undertaken to date on the role of variability in candidate genes that have been examined for association with retinopathy.

Aldose reductase pathway The aldose reductase pathway has been studied in a number of population samples, and variation in the genes expressed in this pathway may influence microvascular susceptibility. Aldose reductase is encoded by the aldose reductase (AR2) gene and is involved in the conversion of glucose to sorbitol, acting as the rate-limiting enzyme of the polyol pathway. The protein is strongly expressed in retinal pericytes and is also found in the vascular endothelium. ${ }^{10}$ It has been postulated that $7 \mathrm{q} 35$ is a susceptibility region for diabetic retinopathy and nephropathy by virtue of the AR2 gene and nearby genes. ${ }^{11}$ It is still uncertain if the AR2 gene itself is directly causative in pre-disposition to retinopathy or protection from its development. ${ }^{12}$ Heesom $\mathrm{et} \mathrm{al}^{13}$ investigated the role of a polymorphism consisting of a $[\mathrm{CA}]_{n}$ repeat in the $5^{\prime}$ region of this gene with severity of retinopathy. No obvious genetic association was detected in subjects segregated by retinopathy status, but a decrease in prevalence of allele $Z+2$ was associated with nephropathy. The same group also reported an increased frequency of the $Z-2$ allele in subjects with neuropathy. ${ }^{14}$ Fujisawa et al ${ }^{15}$ postulated that the length of the polymorphism and not the actual repeat itself was important, concluding that shorter alleles were associated with retinopathy. They compared their findings with other studies on AR2 and retinopathy and concluded that the data were consistent. Most studies of the genetics of the AR2 gene pathway have been conducted in subjects ${ }^{16-21}$ of Asian descent, but recently Demaine $e t a^{22}$ reported a significant association of a particular haplotype with the development of severe retinopathy in Caucasian subjects.

MHC and immunity markers In the case of Type 1 diabetes, the strongest genetic risk component is localised within the major histocompatibility complex (MHC) and is designated IDDM I. This locus contains the HLA-DQ genes and other MHC-encoding genes that contribute to risk of Type 1 diabetes depending on the ethnic population investigated. This HLA region, that is located on $6 \mathrm{p} 21$, has also been implicated as a genomic region of interest for susceptibility to retinopathy in both Type $1^{23-27}$ and Type $2^{27,28}$ diabetes. However, the results appear to vary based on retinopathy classification (see Table 1) and ethnicity, and could be clarified by replication in large samples of adult patients.

Glucose transporters Another potential candidate gene is the glucose transporter 1 (GLUT1), which encodes a 
protein that facilitates transport of glucose into cells. It has been implicated as a susceptibility factor for Type 2 diabetes itself and in the development of microvascular complications. In the three studies listed in Table 1, no association between polymorphisms in the GLUT1 gene and retinopathy status was found..$^{29-31}$

Cell communication and the extracellular matrix A number of other candidate genes involved in cellular communication and the extracellular matrix have also been investigated for genetic association with retinopathy including plasminogen-activating factor (PAI-1), ${ }^{32,33} \mathrm{APOE}^{33}$ tumour necrosis factor alpha $(\mathrm{TNF}-\alpha){ }^{34} \beta-3$ adrenergic receptor gene ( $\left.\beta-3 \mathrm{AR}\right),{ }^{35,36}$ Paraoxonase 1 (PON1), ${ }^{37,38} \alpha 2 \beta 1$ integrin, ${ }^{39}$ collagen IV $\alpha 11^{40,41}$ G-protein $\beta-3$ subunit ${ }^{42}$ and neuropeptide $Y^{43}$ However, in some cases, there were no consistent associations with frequency or severity of retinopathy, and, in others, significant associations have not been replicated in additional patient groups.

Endothelins and nitric oxide synthases There is incontrovertible evidence that endothelium-mediated vasoregulation is defective in diabetes mellitus and is a precursor to pathological alterations in retinal blood flow. ${ }^{44-46}$ The complex interactions between vasodilator and vasoconstrictor modulation of blood flow in the retinal microcirculation are unclear, and the longitudinal influence of diabetes on this interplay is even less well understood. What is clear, however, is that over a period of time, in diabetes, the retinal vasculature undergoes a series of irreversible pathological changes culminating in a severe retinopathy. ${ }^{47}$

A variety of molecules with potent vasoactive functions are produced and released by the vascular endothelium. These include the nitric oxide synthases (NOS) that mediate vasodilation and the endothelins (ETs) that are vasoconstrictors. Angiotensin-converting enzyme (ACE), which converts angiotensinogen to angiotensin, is another important mediator of vasoconstriction and homeostasis; however, studies to date on genetic markers of members ${ }^{48-56}$ of this signalling pathway have not shown definitive evidence of direct genetic risk (see Table 1).

NOS catalyse the formation of the potent vasodilator gaseous molecule NO from the substrate L-arginine. ${ }^{57}$ There are three isoforms of NOS, each of which is encoded by a distinct gene. NOS1 is constitutively expressed in the brain and thus termed neuronal NOS. The NOS3 gene is expressed constitutively in the endothelium of blood vessels (endothelial NOS) and is responsible for the normal dilator tone. NOS2A is not expressed in any tissue under normal conditions. However, upregulation of NOS2A in a variety of tissues by cytokines can result in a sudden burst of NO synthesis leading to severe vasodilation and circulatory collapse.

The ETs are a class of long-acting vasoconstrictor peptides with marked similarity to snake venom, sarafotoxin. There are three different endothelin peptides, ET-1, ET-2, and ET-3, encoded by the EDN1, EDN2, and EDN3 genes, respectively, which are located on different chromosomes. All three EDN genes translate a large precursor, which is cleaved by an endothelinconverting enzyme (ECE) to the active peptide. The most potent vasoconstrictor peptide produced and released from the endothelium is ET-1 where ECE1 cleaves the inactive precursor peptide, big ET-1, to the active ET-1 peptide ${ }^{58}$ and is critical in controlling the production of ET-1. ${ }^{59,60}$ The ETs are vasoconstrictors and are mitogens for vascular smooth muscle. ${ }^{61}$ Expression of ECE1 is widespread in human tissues, but particularly high in vascular endothelial cells. NOS and ET are counterregulatory and the NO/ET pathway is crucial to the state or tone of the vasculature, which is delicately controlled by the balance in their expression. A number of studies have identified perturbations of the NO/ET pathway in most vascular beds including that of the retina in the early stages of diabetes. There has been substantial interest in the polymorphic variability of NOS and ET genes as potential markers for vascular disease.

In studies from our laboratory, we identified microsatellite polymorphic markers in members of the ET and NOS families as well as those of the ECE1 gene. Segregation of the alleles was assessed for diabetic retinopathy in two separate populations of patients recruited from two distinct geographical locations (Northern Ireland and Liverpool, England). ${ }^{62}$ Subjects with no retinopathy despite 15 years or more of diabetes (controls) and any subject with severe retinopathy regardless of duration (ETDRS level 50 or worse) were prospectively recruited into these studies. None of the polymorphisms studied in the NOS1 (unpublished data) or NOS $3^{63}$ genes was significantly associated with cases or controls. However, studies on the NOS2A gene showed that a 14-repeat allele of a pentanucleotide polymorphism in the $5^{\prime} \mathrm{UTR}$ of the NOS2A gene was protective $(\mathrm{OR}=0.21)$ against developing diabetic retinopathy in both patient populations. ${ }^{62}$ Further in vitro studies using constructs of the NOS2A gene showed that this polymorphism influenced cytokine-induced NOS2A transcription. ${ }^{62}$ Increasing allele size resulted in better transcription, with peak transcription occurring in constructs containing the 14-repeat allele. Further increases in allele size $(15,16$, and 17 repeats) did not improve transcription. ${ }^{62}$ When similar experiments were conducted in the presence of high concentrations of glucose mimicking a diabetic state, there was inhibition of NOS2A transcription, but this inhibition effect was 
minimal in constructs containing the 14-repeat allele. ${ }^{62}$ These findings suggest a plausible mechanism for the protective effects seen with the 14-repeat allele, and this is in agreement with published studies on the expression of NOS3 and NOS2A in high glucose. The level of expression of NOS3 is reduced in the retinal vascular endothelial cells in vivo ${ }^{64}$ and in vitro ${ }^{65}$ in a diabetic milieu. There is evidence to suggest that when NOS3 expression is low, induction of NOS2A may occur in an attempt to achieve homeostasis. ${ }^{66}$ Inducibility of NOS2A may be crucial in preventing or delaying pathological alterations in the microcirculation in diabetes. It is noteworthy that specific alleles of the NOS2A were associated with the absence of retinopathy suggesting that vascular damage is the inevitable consequence of a prolonged high glucose environment unless genetic variation confers protection.

A recent review has highlighted the importance of the ET system and the impact of perturbations in this system on vascular complications ${ }^{67}$ in diabetes. Evidence from EDN1 genetic mutants shows that ET and its converting enzyme are necessary for correct vascular development in the embryo. ${ }^{68-70}$ Huang et $a l^{71}$ reported that the EDN1 gene was directly involved in hypertension, and polymorphisms in the gene encoding ET receptor-A have been shown to be associated with essential hypertension testifying to the necessity of balance within the system for normal functioning in vascular tissues. ${ }^{72}$

While we have reported on the importance of ET-1 expression in retinal microvasculature in high glucose, ${ }^{73}$ there appears to be a lack of association between a polymorphism in the EDN1 gene and diabetic retinopathy after correction. ${ }^{63}$ There is also a similar lack of association between the ECE1 gene and retinopathy status after correction (data in preparation).

\section{Conclusions}

The loci summarised in Table 1 have been logical choices for candidate genes to investigate potential genetic contribution to diabetic retinopathy. A number of these loci showed modest associations with either lack of retinopathy or severe retinopathy, indicating the presence of genetic determinants for resistance or susceptibility to vascular complications. However, there appears to be an inability to replicate findings of either positive or negative associations (ie association or lack thereof) in multiple population groups. These inconsistencies may reflect variation in (a) case definition, (b) standardisation of grading of severity of retinopathy, (c) delineation of duration of disease, and (d) accurate recording of other associated risk factors. In addition, there is a tendency for the studies to be relatively small, and often they were undertaken in specific ethnic groups. Thus the role of 'genetic influences' in diabetic retinopathy has been difficult to define.

It is increasingly obvious that there are distinct morphological manifestations in diabetic retinopathy with some subjects showing exudative changes only in the macula (maculopathy) and others showing much more extensive retinal vascular disease. To date, the factors that determine the evolution of the clinical picture of retinopathy have not been identified and it is unclear whether the different morphologies represent distinct pathogenetic mechanisms. Future studies should undertake a more accurate and defined phenotype with respect to retinopathy status, to ensure that subsequent recategorisation can be undertaken if necessary. Agreed international standards for data collection, particularly agreement on a minimum data set for the phenotyping of retinopathy in subjects with diabetes, would permit the pooling of data from the many studies with enhanced power to detect associations. Among the various pathways that have been explored in the association studies thus far, variations in the genes involved in the NOS/ET pathway and the aldose reductase (AR2) pathway represent a fruitful area for further study.

\section{Acknowledgement}

This work was supported by a grant from the Guide Dogs for the Blind.

\section{References}

1 Nebert DW, Petersen DD, Puga A. Human A locus polymorphism and cancer: inducibility of CYP1A1 and other genes by combustion products and dioxin. Pharmacogenetics 1991; 1: 68-78.

2 Redondo MJ, Fain PR, Eisenbarth GS. Genetics of type 1A diabetes. Recent Prog Horm Res 2001; 56: 69-89.

3 Moss SE, Klein R, Klein BEK. 10-year incidence of visual loss in a diabetic population. Ophthalmology 1994; 101: 1061-1070.

4 Diabetes Control and Complications Trial Research Group. Clustering of long term complications in families with diabetes in the Diabetes Control \& Complication Trial. Diabetes 1997; 46: 1829-1839.

5 Leslie RDG, Pyke DA. Diabetic retinopathy in identical twins. Diabetes 1982; 31: 19-21.

6 Guillausseau PJ, Tielmans D, Virally-Monod M, Assayag M. Diabetes: from phenotypes to genotypes. Diabetes Metab 1997; 23: 14-21.

7 Cruickshanks KJ, Vadheim CM, Moss SE, Roth MP, Riley WJ, MacLaren NK. Genetic marker associations with proliferative retinopathy in persons diagnosed with diabetes before $30 \mathrm{yr}$ of age. Diabetes 1992; 41: 879-885.

8 Rich SS, Freedman BI, Bowden DW. Genetic epidemiology of diabetic complications. Diabetic Rev 1997; 5: 165-173.

9 Imperatore G, Hanson RL, Pettitt DJ, Kobes S, Bennett PH, Knowler WC. Sib-pair linkage analysis for susceptibility genes for microvascular complications among Pima Indians with type 2 diabetes. Diabetes 1998; 47: 821-830. 
10 Vinores SA, Van Niel E, Swerdloff JL, Campochiaro PA. Electron microscopic immunocytochemical demonstration of blood-retinal barrier breakdown in human diabetics and its association with aldose reductase in retinal vascular endothelium and retinal pigment epithelium. Histochem $J$ 1993; 25: 648-663.

11 Patel A, Hibberd ML, Millward BA, Demaine AG. Chromosome 7q35 and susceptibility to diabetic micro-vascular complications. J Diabetes Complications 1996; 10: 62-67.

12 Pfeiffer MA, Schumer MP, Gelber DA. Aldose reductase inhibitors: the end of an era or the need for different trial designs? Diabetes 1994; 42: S82-S89.

13 Heesom AE, Hibberd ML, Millward A, Demaine AG. Polymorphism in the $5^{\prime}$-end of the aldose reductase gene is strongly associated with the development of diabetic nephropathy in type I diabetes. Diabetes 1997; 46: 287-291.

14 Heesom AE, Millward A, Demaine AG. Susceptibility to diabetic neuropathy in patients with insulin dependent diabetes mellitus is associated with a polymorphism at the $5^{\prime}$ end of the aldose reductase gene. J Neurol Neurosurg Psychiatry 1998; 64: 213-216.

15 Kao YL, Donaghue K, Chan A, Knight J, Silink M. A novel polymorphism in the aldose reductase gene promoter region is strongly associated with diabetic retinopathy in adolescents with Type 1 diabetes. Diabetes 1999; 48: 1338-1340.

16 Olmos P, Acosta AM, Schaffiano R, Diaz R, Alvarado D, $\mathrm{O}^{\prime}$ Brien A et al. Aldose reductase gene polymorphism and rate of appearance of retinopathy in non-insulin dependent diabetics. Rev Med Chile 1999; 127: 399-409.

17 Ko BCB, Lam KSL, Wat NMS, Chung SS. An (A-C)n dinucleotide repeat polymorphic marker at the $5^{\prime}$ end of the aldose reductase gene is associated with early onset diabetic retinopathy in NIDDM patients. Diabetes 1995; 44: 727-732.

18 Fujisawa T, Ikegami H, Kawaguchi Y, Yamato E, Nakagawa $Y$, Shen GQ et al. Length rather than a specific allele of dinucleotide repeat in the $5^{\prime}$ upstream region of the aldose reductase gene is associated with diabetic retinopathy. Diabetic Med 1999; 16: 1044-1047.

19 Ichikawa F, Yamada K, Ishiyama-Shigemoto S, Yuan X, Nonaka K. Association of an $(\mathrm{A}-\mathrm{C}) n$ dinucleotide repeat polymorphic marker at the $5^{\prime}$-region of the aldose reductase gene with retinopathy but not with nephropathy or neuropathy in Japanese patients with Type 2 diabetes mellitus. Diabetic Med 1999; 16: 744-748.

20 Ikegishi Y, Tawata M, Aida K, Onaya T. Z-4 allele upstream of the aldose reductase gene is associated with proliferative retinopathy in Japanese patients with NIDDM, and elevated luciferase gene transcription in vitro. Life Sci 1999; 65: 2061-2070.

21 Chistiakov DA, Turakulov RI, Gorashko NM, Demurov LM, Rachiba IuM, Kondrat_ev IaIu. Polymorphism of a dinucleotide repeat within the aldose reductase gene in normalcy and insulin-dependent diabetes with vascular complications. Mol Biol 1997; 31: 660-664.

22 Demaine A, Cross D, Millward A. Polymorphisms of the aldose reductase gene and susceptibility to retinopathy in type 1 diabetes mellitus. Invest Ophthalmol Vis Sci 2000; 41: 4064-4068.

23 Cisse A, Chauffert M Diop SN, Chevenne D, Sidibe EH, Michel S et al HLA markers and diabetic retinopathy in the Senegalese population. Dakar Med 1998; 43: 29-33.

24 Falck AA, Knip JM, Ilonen JS, Laatikainen LT. Genetic markers in early diabetic retinopathy of adolescents with type I diabetes. J Diabetes Complications 1997; 11: 203-207.
25 Agardh D, Gaur LK, Agardh E, Landin-Olsson M, Agardh CD, Lernmark A. HLA-DQB1*0201/0302 is associated with severe retinopathy in patients with IDDM. Diabetologia 1996; 39: 1313-1317.

26 Stewart LL, Field LL, Ross S, McArthur RG. Genetic risk factors in diabetic retinopathy. Diabetologia 1993; 36: 1293-1298.

27 Serrano-Rios M, Regueiro JR, Serverino R, Lopez-Larrea C, Arnaiz-Villena A. HLA antigens in insulin dependent and non-insulin dependent Spanish diabetic patients. Diabetes Metab 1983; 9: 116-120.

28 Hawrami K, Mohan R, Mohan V, Hitman GA. A genetic study of retinopathy in south Indian Type 2 diabetic patients. Diabetologia 1991; 34: 441-444.

29 Gutierrez C, Vendrell J, Pastor R, Broch M, Aguilar C, Llor C et al. GLUT1 gene polymorphism in non-insulin-dependent diabetes mellitus: genetic susceptibility relationship with cardiovascular risk factors and microangiopathic complications in a Mediterranean population. Diabetes Res Clin Pract 1998; 41: 113-120.

30 Hodgkinson AD, Millward BA, Demaine AG. Polymorphisms of the glucose transporter (GLUT1) gene are associated with diabetic nephropathy. kidney Int 2001; 59: 985-989.

31 Liu ZH, Guan TJ, Chen ZH, Li LS. Glucose transporter (GLUT1) allele (XbaI-)associated with nephropathy in noninsulin-dependent diabetes mellitus. Kidney Int 1999; 55: 1843-1848.

32 Nagi DK, McCormack LJ, Mohamed-Ali V, Yudkin JS, Knowler WC, Grant PJ. Diabetic retinopathy, promoter (4G/ 5G) polymorphism of PAI-1 gene, and PAI-1 activity in Pima Indian with Type 2 diabetes. Diabetes Care 1997; 20: 1304-1309.

33 Tarnow L, Stehouwer CD, Emeis JJ, Poirier O, Cambien F, Hansen BV et al. Plasminogen activator inhibitor-1 and apolipoprotein E gene polymorphisms and diabetic angiopathy. Nephrol Dial Transplant 2000; 15: 625-630.

34 Hawrami K, Hitman GA, Rema M, Snehalatha C, Viswanathan M, Ramachandran A et al. An association in non-insulin dependent diabetes mellitus subjects between susceptibility to retinopathy and tumour necrosis factor polymorphism. Hum Immunol 1996; 46: 49-54.

35 Sakane N, Yoshida T, Yoshioka K, Kondo M, Sakai Y, Takahashi T. Beta(3)-adrenoreceptor gene polymorphism: a newly defined risk factor for proliferative retinopathy in NIDDM patients. Diabetes 1997; 46: 1633-1636.

36 Vendrell J, Gutierrez C, Broch M, Fernandez_Real JM, Aguilar C, Richart C. Beta 3-adrenoreceptor gene polymorphism and leptin. Lack of relationship in type 2 diabetic patients. Clin Endocrinol 1998; 49: 679-683.

37 Kao YL, Donaghue K, Chan A, Knight J, Silink M. A variant of paraoxonase (PON1) gene is associated with diabetic retinopathy in IDDM. J Clin Endocrinol Metab 1998; 83: 2589-2592.

38 Mackness B, Durrington PN, Abuashia B, Boulton AJ, Mackness MI. Low paraoxonase activity in type II diabetes mellitus complicated by retinopathy. Clin Sci 2000; 98 : 335-363.

39 Matsubara Y, Murata M, Maruyama T, Handa M, Yamagata $\mathrm{N}$, Watanabe $\mathrm{G}$ et al. Association between diabetic retinopathy and genetic variations in alpha2beta1 integrin, a platelet receptor for collagen. Blood 2000; 95: 1560-1564.

40 Alcolado JC, Baroni MG, Li SR, Galton DJ. Genetic variation around the collagen-IV 1A gene locus and proliferative retinopathy in Type 2 diabetes-mellitus. Hum Hered 1993; 43: $126-130$. 
41 Chen JW, Hansen PM, Tarnow L, Hellgren A, Deckert T, Pociot F. Genetic variation of a collagen IV alpha 1-chain gene polymorphism in Danish insulin-dependent diabetes mellitus (IDDM) patients: lack of association to nephropathy and proliferative retinopathy. Diabetic Med 1997; 14: 143-147.

42 Shcherbak NS, Schwartz EI. The C825T polymorphism in the G-protein beta3 subunit gene diabetic complications in IDDM patients. J Hum Genet 2001; 46: 188-191.

43 Niskanen L, Voutilainen-Kaunisto R, Terasvirta M, Koulu $\mathrm{M}$, Pesonen U, Mercuri $\mathrm{M}$ et al. Leucine 7 to proline 7 polymorphism in the neuropeptide y gene is associated with retinopathy in type 2 diabetes. Exp Clin Endocrinol Diabetes 2000; 108: 235-236.

44 Stehouwer CDA, Lambert J, Donker AJM, van Hinsbergh VW. Endothelial dysfunction and pathogenesis of diabetic angiopathy. Cardiovasc Res 1997; 34: 55-68.

45 Feener EP, King GL. Vascular dysfunction in diabetes mellitus. Lancet 1997; 350: 9-13.

46 McVeigh GE, Brennan GM, Johnston GD, McDermott BJ, McGrath LT, Henry W et al. Impaired endothelialdependent and independent vasodilation in patients with Type 2 (non-insulin dependent) diabetes mellitus. Diabetologia 1992; 35: 771-776.

47 Cogan DG, Toussaint D, Kuwabarra T et al. Retinal vascular patterns IV. Diabetic retinopathy Arch Ophthalmol 1961; 66: 366-378.

48 Gutierrez C, Vendrell J, Pastor R, Llor C, Aguilar C, Broch M et al. Angiotensin I converting enzyme an angiotensinogen gene polymorphisms in non-insulin-dependent diabetes mellitus. Lack of relationship with diabetic nephropathy and retinopathy in a Caucasian Mediterranean population. Metab Clin Exp 1997; 46: 976-980.

49 Fujisawa T, Ikegami H, Kawaguchi Y, Hamada Y, Ueda H, Shintani $\mathrm{M}$ et al. Meta-analysis of association of insertion/ deletion polymorphism of angiotensin I-converting enzyme gene with diabetic nephropathy and retinopathy. Diabetologia 1998; 41: 47-53.

50 Nagi DK, Mansfield MW, Stickland MH, Grant PJ. Angiotensin converting enzyme (ACE) insertion/deletion (I/D) polymorphism and diabetic retinopathy in subjects with IDDM and NIDDM. Diabetic Med 1995; 12: 997-1001.

51 Fujisawa T, Ikegami H, Shen GQ, Yamato E, Takekawa K, Nakagawa $\mathrm{Y}$ et al. Angiotensin I-converting enzyme gene polymorphism is associated with myocardial infraction, but not with retinopathy or nephropathy, in NIDDM. Diabetes Care 1995; 18: 983-985.

52 Hanyu O, Hanawa H, Nakagawa O, Tani N, Andou N, Aizawa $\mathrm{Y}$ et al. Polymorphism of the angiotensin I-converting enzyme gene in diabetic nephropathy in Type II diabetic patients with proliferative retinopathy. Renal Failure 1998; 20: 125-133.

53 Rabensteiner D, Abrahamian H, Irsigler K, Kiener HP, Mayer G, Kaider A et al. ACE gene polymorphism and proliferative retinopathy in type 1 diabetes: results of a case-control study. Diabetes Care 1999; 22: 1530-1535.

54 Matsumoto A, Iwashima Y, Abiko A, Morikawa A, Sekiguchi M, Eto $M$ et al. Detection of the association between a deletion polymorphism in the gene encoding angiotensin I-converting enzyme and advanced diabetic retinopathy. Diabetes Res Clin Pract 2000; 50: 195-202.

55 Tarnow L, Cambien F, Rossing P, Nielsen FS, Hansen BV, Lecerf $\mathrm{L}$ et al. Lack of relationship between an insertion/ deletion polymorphism in the angiotensin I-converting enzyme gene and diabetic nephropathy and proliferative retinopathy in IDDM patients. Diabetes 1995; 44: 489-494.
56 Tarnow L, Cambien F, Rossing P, Nielsen FS, Hansen BV, Ricard $\mathrm{S}$ et al. Angiotensin-II type 1 receptor gene polymorphism and diabetic microangiopathy. Nephrol Dial Transplant 1996; 11: 1019-1023.

57 Sheng H, Ignarro LJ. Biochemical and immunohistochemical characterisation of nitric-oxide synthase in the rat retina. Pharm Res 1996; 33: 29-34.

58 Russell FD, Davenport AP. Secretory pathways in endothelin synthesis. Br J Pharm 1999; 126: 391-398.

59 Shao R, Yan W, Rockey DC. Regulation of endothelin-1 synthesis by endothelin converting enzyme-1 during wound healing. J Biol Chem 1999; 274: 3228-3234.

60 Telemaque S, Emoto N, deWit D, Yanagisawa M. In vivo role of endothelin converting enzyme- 1 as examined by adeno-virus mediated overexpression in rats. J Cardiovasc Pharmacol 1998; 31: S548-S550.

61 Miyauchi T, Masaki T. Pathophysiology of endothelin in the cardiovascular system. Annu Rev Physiol 1999; 61: 391-415.

62 Warpeha KM, Xu W, Liu L, Charles IG, Patterson CC, $\mathrm{Ah} \_$Fat $\mathrm{F}$ et al. Genotyping and functional analysis of a polymorphic (CCTTT) $(n)$ repeat of NOS2A in diabetic retinopathy. FASEB J 1999; 13: 1825-1832.

63 Warpeha KM, Ah-Fat F, Harding S, Patterson CC, Xu W, Hart PM et al. Dinucleotide repeat polymorphisms in EDN1 and NOS3 are not associated with severe diabetic retinopathy in Type 1 and Type 2 diabetes. EYE 1999; 13: 174-178.

64 Tesfamariam B, Brown ML, Deykin D, Cohen RA. Elevated glucose promotes generation of endothelium-derived vasoconstrictor protanoids in rabbit aorta. J Clin Invest 1990; 85: 929-932.

65 Chakravarthy U, Hayes RG, Stitt AW, McAuley E, Archer DB. Constitutive nitric oxide synthase expression in retinal vascular endothelial cells is suppressed by high glucose and advanced glycation end products. Diabetes 1998; 47: 945-952.

66 Graier WF, Wascher TC, Lockner L, Toplak H, Krejs GJ, Kukovetz WR. Exposure to elevated D-glucose concentrations modulates vascular endothelial cell vasodilatory responses. Diabetes 1993; 42: 1497-1505.

67 Hopfner RL, Gopalakrishnan V. Endothelin: emerging role in diabetic vascular complications. Diabetologia 1999; 42: 1383-1394.

68 Kurihara Y, Kurihara H, Suzuki H, Kodama T, Maemura K, Nagai $R$ et al. Elevated blood pressure and craniofacial abnomalities in mice deficient in endothelin-1. Nature 1994; 368: 703-710.

69 Yanagisawa Y, Yanagisawa M, Kapur R, Richardson JA, Williams SC, Clouthier DE et al. Dual genetic pathways of endothelin-mediated intercellular signalling revealed by targeted disruption of endothelin converting enzyme-1 gene. Development 1998; 125: 825-836.

70 Brand M, Le Moullec J-M, Corvol P, Gasc JM. Ontogeny of endothelins-1 and -3 . Their receptors, and endothelin converting enzymes- 1 in the early human embryo. J Clin Invest 1998; 101: 549-559.

71 Huang PL, Huang Z, Mashimo H, Bloch KD, Moskowitz MA, Bevan JA et al. Hypertension in mice lacking the gene for endothelial nitric oxide synthase. Nature 1995; 377: 239-242.

72 Stevens PA, Brown MJ. Genetic variability of the ET-1 and the $\mathrm{ET}_{\mathrm{A}}$ receptor genes in essential hypertension. J Cardiovasc Pharm 1995; 26: S9-S12.

73 Chakravarthy U, Hayes RG, Stitt AW, Douglas A. Increased ET1 expression in ocular tissues of diabetic animals. Invest Ophthalmol 1997; 38: 2144-2151. 